Louisiana State University

LSU Digital Commons

Faculty Publications

Department of Oceanography \& Coastal

Sciences

2014

\title{
Luminate: Linking Agricultural Land Use, Local Water Quality And Gulf Of Mexico Hypoxia
}

C L. Kling

amvalcu@iastate.edu

Y Panagopoulos

S S. Rabotyagov

A M. Valcu

C L. Kling

See next page for additional authors

Follow this and additional works at: https://digitalcommons.Isu.edu/oceanography_coastal_pubs

\section{Recommended Citation}

Kling, C. L., Panagopoulos, Y., Rabotyagov, S. S., Valcu, A. M., Kling, C. L., Campbell, T., White, M. J., Arnold, J. G., Srinivasan, R., Jha, M. K., Richardson, J. J., Moskal, L. M., Turner, R., \& Rabalais, N. N. (2014). Luminate: Linking Agricultural Land Use, Local Water Quality And Gulf Of Mexico Hypoxia. European Review Of Agricultural Economics, 41 (3), 431-459. https://doi.org/10.1093/erae/jbu009

This Article is brought to you for free and open access by the Department of Oceanography \& Coastal Sciences at LSU Digital Commons. It has been accepted for inclusion in Faculty Publications by an authorized administrator of LSU Digital Commons. For more information, please contact ir@lsu.edu. 


\section{Authors}

C L. Kling, Y Panagopoulos, S S. Rabotyagov, A M. Valcu, C L. Kling, T Campbell, M J. White, J G. Arnold, R Srinivasan, M K. Jha, J J. Richardson, L M. Moskal, R. Eugene Turner, and N N. Rabalais 


\title{
LUMINATE: linking agricultural land use, local water quality and Gulf of Mexico hypoxia
}

Catherine L. Kling ${ }^{\dagger}$, Yiannis Panagopoulos ${ }^{\dagger}$, Sergey S. Rabotyagov ${ }^{\ddagger}$, Adriana M. Valcu ${ }^{\dagger} *$, Philip W. Gassman ${ }^{\dagger}$, Todd Campbell ${ }^{\dagger}$, Michael J. White ${ }^{\S}$, Jeffrey G. Arnold ${ }^{\S}$, Raghavan Srinivasan ${ }^{\top}$, Manoj K. Jha**, Jeffrey J. Richardson ${ }^{\ddagger}$, L. Monika Moskal ${ }^{\ddagger}$, R. Eugene Turner ${ }^{\dagger \dagger, \S \S}$ and Nancy N. Rabalais ${ }^{\text {"ब }}$.

${ }^{\dagger}$ Centre for Agricultural and Rural Development, Iowa State University, USA; ${ }^{\ddagger}$ University of Washington, College of the Environment, School of Environmental and Forest Sciences, USA; ${ }^{\S}$ USDA-ARS Grassland, Soil and Water Research Lab, Temple, TX, USA; "Texas A\&M University, USA; ${ }^{* *}$ North Carolina A\&T State University, USA; ${ }^{\dagger \dagger}$ Coastal Ecology Institute and Department of Oceanography and Coastal Sciences, Louisiana State University, USA; ${ }^{\S \S}$ Louisiana State University, USA; ${ }^{\boldsymbol{9}}$ Louisiana Universities Marine Consortium, Chauvin, KY, USA

Received February 2014; final version accepted April 2014

Review coordinated by Steve McCorriston

\begin{abstract}
In this paper, we discuss the importance of developing integrated assessment models to support the design and implementation of policies to address water quality problems associated with agricultural pollution. We describe a new modelling system, LUMINATE, which links land use decisions made at the field scale in the Upper Mississippi, Ohio and Tennessee Basins through both environmental and hydrological components to downstream water quality effects and hypoxia in the Gulf of Mexico. This modelling system can be used to analyse detailed policy scenarios identifying the costs of the policies and their resulting benefits for improved local and regional water quality. We demonstrate the model's capabilities with a simple scenario where cover crops are incentivised with green payments over a large expanse of the watershed.
\end{abstract}

Keywords: integrate modelling, land use change, Gulf of Mexico Hypoxia, LUMINATE, water quality

JEL classification: Q51, Q52, Q57 


\section{Introduction}

Water quality problems remain ubiquitous around the world and in many locations are growing in severity. Nutrient enrichment of freshwater and coastal areas from a variety of human activities including agricultural runoff, sewage and industrial sources is the most prevalent type of water quality problem. ${ }^{1}$ The delivery of nutrients, primarily nitrogen $(\mathrm{N})$ and phosphorus $(\mathrm{P})$, into waterways accelerates normal plant growth in a process called eutrophication. Eutrophication of water bodies results in a range of lost ecosystem services (Tilman et al., 2001; Chislock et al., 2013) whose values are increasingly understood and monetised (e.g. Knowler, Barbier and Strand, 2001; Massey, Newbold and Gentner, 2006; Polasky and Segerson, 2009; Barbier, 2012; Huang et al., 2012). For example, eutrophication problems in local freshwater systems such as lakes and streams can include excess algae growth, changes in water clarity, odour and toxic algae blooms. In addition to these local effects, excess nutrients cause detrimental effects far downstream in the coastal areas, including the creation of oxygen-depleted (hypoxic) waters. In the last 50 years, hypoxia became a global problem with $>415$ areas across the world had been or are experiencing its symptoms. Among these areas, 169 have been identified as hypoxic zones, 233 as areas of concerns and 13 areas as recovered (Selman et al., 2008).

Management of excess nutrient input into aquatic systems is a 'wicked' problem, incorporating a range of scientific and policy challenges (Turner, 2000; Elofsson, Folmer and Gren, 2003; Smith and Schindler, 2009; Chen and Hong, 2012; Rabotyagov et al., 2014). In addition, the understanding of eutrophication impacts, its costs and benefits are both increasing and highly dependent on the particular system under study (Chen and Hong, 2012). A common theme and challenge is one of integration, both across space (from terrestrial ecosystems to freshwater and marine aquatic systems) and across disciplines. $^{2}$

The impetus for integrated modelling has often been provided by public entities looking to develop policy responses to these problems, with the Baltic Sea Action Plan, ${ }^{3}$ the Black Sea Ecosystem Recovery Project, ${ }^{4}$ the environmental policies in the Mediterranean Sea (Karydis and Kitsiou, 2012), Gulf Hypoxia Action Plan (USEPA, 2001, 2008) and the Chesapeake Bay Program (USEPA, 2009) serving as notable examples in the developed world, with subsequent efforts in the developing countries to extend coastal management to upstream watersheds (Chen and Hong, 2012). ${ }^{5}$ In almost all cases, explicit

1 http://www.un.org/waterforlifedecade/quality.shtml.

2 While the focus of this paper is agriculture and water quality, the recognition for better integration across ecosystems and disciplines has produced fruitful collaborations between economists and other scientists in other contexts as well (see, for example, the work of the Natural Capital Project: http://www.naturalcapitalproject.org/).

3 www.helcom.fi.

4 http://www.elmed-rostov.ru/Projects/BSERPper cent20Visitcard/.

5 http://water.epa.gov/type/watersheds/named/msbasin/upload/2008_8_28_msbasin_ghap2008_ update082608.pdf. 
recognition of the linkage between upstream landscapes and marine systems leads to the need to carefully consider the role of agricultural landscapes. This is especially true in the European Union and the United States, where agricultural sources are the most significant contributors to eutrophication; ${ }^{6}$ however, wastewater from sewage and industry are viewed as the main pollutant contributors in Latin America, Asia and Africa (Selman et al., 2008).

In the European Union, the Baltic Sea and the Black Sea ecosystems are two examples of agriculture impacting eutrophication. The increased agricultural activity that followed the inclusion of the Baltic countries in the EU also increased the amount of nutrients delivered to the Baltic Sea hence increasing the size of the eutrophic zone. On the other hand, the Black Sea ecosystem is currently identified as a system in recovery due to a decreased agricultural activity that followed the collapse of the former Soviet Union (Selman et al., 2008, http://blacksea-education.ru/e2-1.shtml).

A striking example of the nexus between large-scale eutrophication problems with both detrimental local water quality effects and major downstream problems and agriculture occurs in the Corn Belt region in the central United States. The Upper Mississippi River Basin (UMRB) and Ohio-Tennessee River Basin (OTRB), which comprise most of the Corn Belt, each exhibit significant local water quality problems (USEPA, 2014), and contribute a significant share of nutrient loadings to the Northern Gulf of Mexico where excess nutrients result in a second-largest annual hypoxic zone in the world (USEPASAB, 2007). Since 1985, Rabalais and others have documented the annual extent of the seasonal hypoxic zone that forms in the Northern Gulf of Mexico (Turner, Rabalais and Justic, 2006; Rabalais et al., 2010). Figure 1 shows the size and location of the watersheds in relation to the hypoxic zone.

Agricultural production has been a major land use activity for nearly 200 years in much of the UMRB and OTRB. Currently, the majority of US agricultural exports as well as the majority of the world's feed grain and soybean exports are produced in these two major Corn Belt watersheds. The current agricultural land use patterns in the UMRB and OTRB have resulted from the simultaneous decisions of over half a million individual landowners and agricultural producers over decades. These decisions have been influenced by crop profitability dictated in turn by economic conditions including commodity and energy policy. When scaled up to the basin level, the result has been a highly productive agricultural region, but with significant degradation to water quality and other ecosystem services.

Federal and state governments are actively looking for solutions and a number of conservation actions (abatement options) that can reduce nutrient losses from agriculture are available. However, to be effective (and even more so in order to be cost-effective) the cumulative and non-linear effects

6 For example, for the Baltic Sea, it has been found that the desired conditions cannot be achieved without reducing diffuse (non-point) sources (http://meeting.helcom.fi/c/document_library/ get_file?p_I_id=16324\&folderld=2062738\&name=DLFE-52270.pdf, p. 15), while in the United States, the vast majority of nitrogen impairment is due to non-point sources (Ribaudo et al., 2008). 


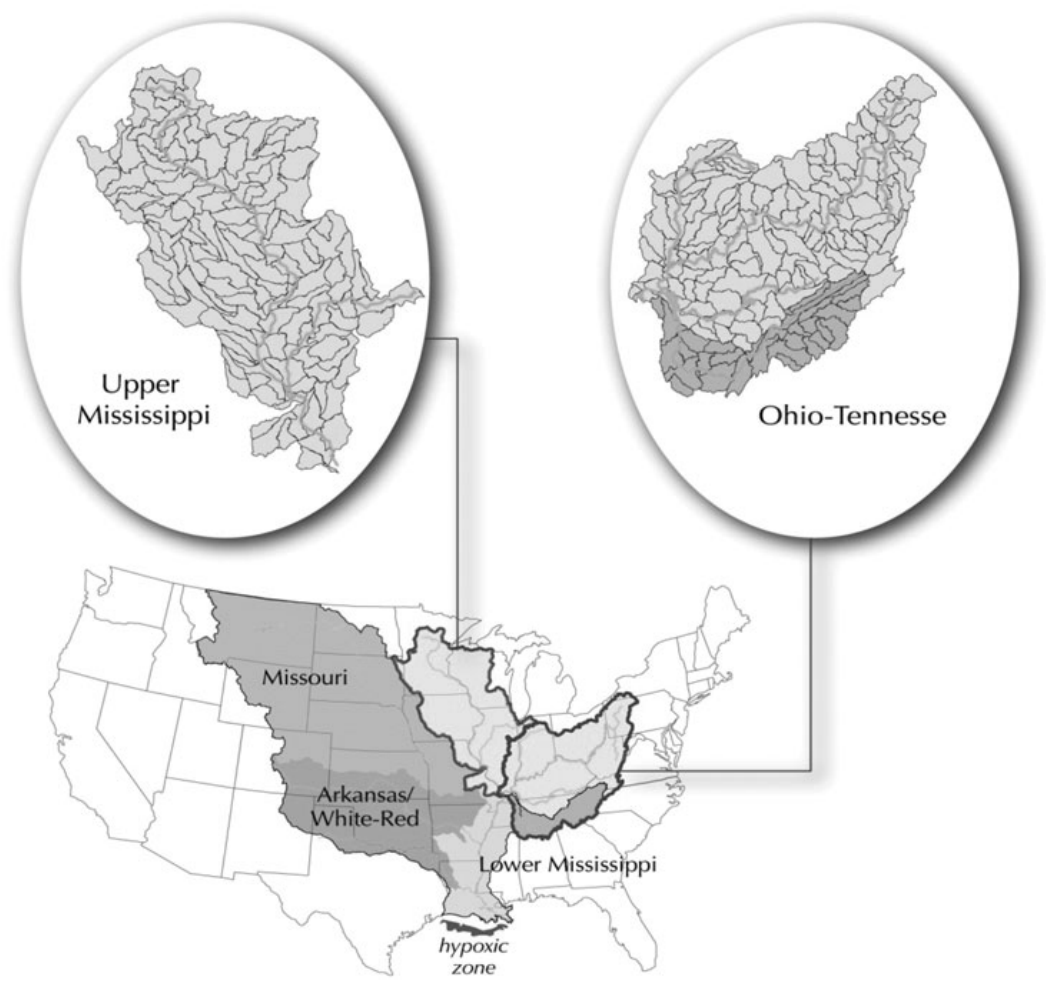

Fig. 1. Location of the URMB and the OTRB within the Mississippi-Atchafalaya River Basin (MARB).

that occur, when abatement activities are adopted on individual farms, need to be accounted for as they are scaled up to the watershed level. For example, if multiple contiguous landowners install conservation practices along a river, this may have significantly more impact on downstream water quality than if the same number install those practices at non-contiguous locations. Likewise, nutrient loadings in some locations in the watershed have a much lower possibility of being transported to the Gulf than others depending on the features of the landscape and hydrology. It is further important to realise that nutrient fate and transport is not, in general, an exogenous physical process, but is in fact endogenous to water quality policy (for example, when a reconstructed wetland effectively traps and removes nutrients from upstream sources) (Randhir, Lee and Engel, 2000; Khanna et al., 2003; Rabotyagov, Valcu and Kling, 2013; Shortle and Horan, 2013). Equally important is to recognise that the costs of adopting abatement actions vary by location as a function of soil characteristics, farming practices, weather patterns and a host of other location-specific features. An integrated modelling system that incorporates these non-linearities, scale effects and cost variability will be essential for good public policy.

In this study, we describe the development and implementation of an integrated assessment model for this large region of the central United States. 
Our coupled natural and human system captures the key non-linearities in spatial processes associated with scaling up the impacts of individual decision-making at the agricultural field scale to the impact on local watersheds and the downstream hypoxic conditions. We begin with a brief literature review of integrated land use and water quality assessments for our study region. After describing an overview of the modelling system, we describe the components in more detail. In particular, we describe the development of an ecological production function relating nutrient loadings to the areal extent of Gulf hypoxia. We then present the results of a simple, but detailed, land use scenario where the effects of large-scale placement of cover crops across the UMRB and OTRB are simulated. This simple scenario is used to demonstrate the potential for the modelling system to inform policy as the simulated output includes predictions of the change in water quality throughout the large watersheds (including the local and downstream impacts), the impact on hypoxic zone conditions in the northern Gulf of Mexico, as well as the costs of adopting these practices. The results presented here highlight the value of such a modelling system for policy design and implementation. In the final section, next steps and additional discussion of the potential role of integrated assessment models are described.

\section{Literature review}

In general terms, the literature related to Northern Gulf of Mexico hypoxia and water quality problems in the UMRB and OTRB fall into two broad categories: (i) studies that focus entirely on the biophysical aspects of the processes contributing to the Northern Gulf of Mexico hypoxia and (ii) studies that attempt to integrate the socio-economic and the biophysical aspects of the water quality processes. In the first category, there are studies that focus on the modelling of Northern Gulf of Mexico hypoxia, but do not link to specific land use management strategies (Justić, Rabalais and Turner, 2002; Scavia et al., 2003; Turner, Rabalais and Justic, 2006; Justíc et al., 2007), studies that focus on estimating the nutrient loadings that ultimately reach the Gulf, but cannot perform scenarios relating specific land use changes to the hypoxic zone (Burkart and James, 1999; Donner et al., 2002; Booth and Campbell, 2007; Alexander et al., 2007; Broussard and Turner, 2009), and studies that estimate the nutrient loading and at the same time consider the impact of different land use scenarios (Johnes and Hearhwaite,1997; White et al., 2014).

The 'integrating' modelling literature considers the impact of different land use scenarios on water quality by generally focusing on smaller watersheds rather than a large scale. These studies, although incomplete in one or more dimensions and not providing any direct linkage to Gulf of Mexico hypoxia, offer valuable insights and alternative policy options that have the potential to reduce the size of the hypoxic zone. In some cases, the complex relationship between runoff leaving the field and its impact on the overall water quality is simplified by estimating different proxy alternatives, e.g. delivery coefficients (e.g. Wainger et al., 2013) or point systems (Rabotyagov, Valcu and Kling, 2013). The ultimate goal of these studies is to identify the cost-effective land 
use changes and to design the optimal economic incentives to reduce the runoff in the landscapes dominated by agriculture.

Similarly, within the 'integrating' literature, we can further identify several categories: studies that provide extensive reviews of the programmes that have been implemented, studies that compare the cost-effectiveness of different land use scenarios, studies that consider the optimal placement of the conservation practices or studies that consider the impact of different policies (i.e. biofuel crop production) on water quality.

Ribaudo et al. (2001) compare the cost-effectiveness of a fertiliser standard and wetland restorations as $\mathrm{N}$ reduction methods in the Mississippi basin. Doering et al. (2001) provide an economic analysis for reducing $\mathrm{N}$ on a large scale, but they rely on aggregate data that is not watershed based. Greenhalgh and Sauer (2003) present a comprehensive assessment of different costeffective policy options to alleviate hypoxia, but with a focus on the local water quality issues. Wu and Tanaka (2005) estimate the costs of adopting three different conservation policies and a tax on the use of fertiliser in the UMRB. Secchi et al. (2007) outline a methodology to assess the economics costs and water quality benefits by considering a number of hypothetical land use scenarios for 13 watersheds in Iowa, one of the states with the highest contributions to the hypoxic zone. Jenkins et al. (2010) evaluate the benefits of wetland restoration in the southern part of the Mississippi corridor.

Rabotyagov et al. (2010) integrate a watershed based model with cost data and develop, via evolutionary algorithms, a trade-off frontier for the UMRB specifying the least cost of achieving different level of $\mathrm{N}$ and $\mathrm{P}$ reductions. For the same large watershed, Secchi et al. (2011) assess the water quality changes in the context of an increase in the corn acreage due to an ethanol policy.

\section{Description of study regions}

The UMRB drains $492,000 \mathrm{~km}^{2}$ including large parts of Illinois, Iowa, Minnesota, Missouri and Wisconsin from Lake Itasca in Minnesota to just north of Cairo, Illinois, above the confluence with the Ohio River (Figure 1). The area is referred to as Region 07 by the US Geological Survey (USGS) at a '2-digit watershed' scale and is further composed of 131 USGS '8-digit watersheds' and 5,729 USGS '12-digit subbasins' (USGS, 2012a, 2012b). The average annual UMRB rainfall within the last four decades was $900 \mathrm{~mm}$, ranging from 600 to $1,200 \mathrm{~mm}$ across the basin with values generally decreasing from east to west. Cropland consists mainly of corn-soybean rotations and occupies almost 50 per cent of the total UMRB area, with the majority of the land area consisting of slopes $<5$ per cent.

The OTRB covers $\sim 528,000 \mathrm{~km}^{2}$ including large portions of seven states as shown in Figure 1. The OTRB is composed of 152 8-digit watersheds and 6,350 12-digit subwatersheds. The OTRB region received nearly 1,200 mm/year of average annual rainfall during the last 40 years. About half of the land cover in this basin is forested, with the majority of the remaining area planted in crops (20 per cent) or managed as permanent pasture/hay (15 per cent). Corn, 
soybean and wheat are the major crops grown (Santhi et al., 2014). Compared with the UMRB, the OTRB's slopes are much steeper, especially in the forested Tennessee basin; however, cropland is mostly concentrated in the northwestern part of the region, which is characterised by mild topography.

According to USEPA SAB (2007), 43 per cent of the nitrate-N load and 26 per cent of the total phosphorus (TP) load delivered to the Gulf of Mexico came from the UMRB during 2001-2005, in spite of the fact that the UMRB drains only 15 per cent of the total Gulf of Mexico drainage area. The mean annual in-stream UMRB total nitrogen (nitrate-N plus organic nitrogen) and TP loads measured at Grafton, IL (Figure 3) are 500,000 and 30,000 t/year, respectively (USGS, 2013). Likewise, the OTRB exports roughly 500,000 t of $\mathrm{N}$ annually to the main Mississippi River channel, with close to 67 per cent in the form of nitrate-N. The annual average phosphorus loads measured at the OTRB outlet equal 48,000 t/year (USGS, 2013).

\section{Overview of the LUMINATE system}

Current water quality conditions in the UMRB and OTRB and the delivery of nutrients from these watersheds to the Gulf of Mexico results from the decisions of thousands of agricultural producers concerning crop choice, conservation practices and management choices. These decisions depend in turn on many factors including soil type, climate, expected market prices and policy variables such as subsidy levels. Figure 2 describes the basic components and model

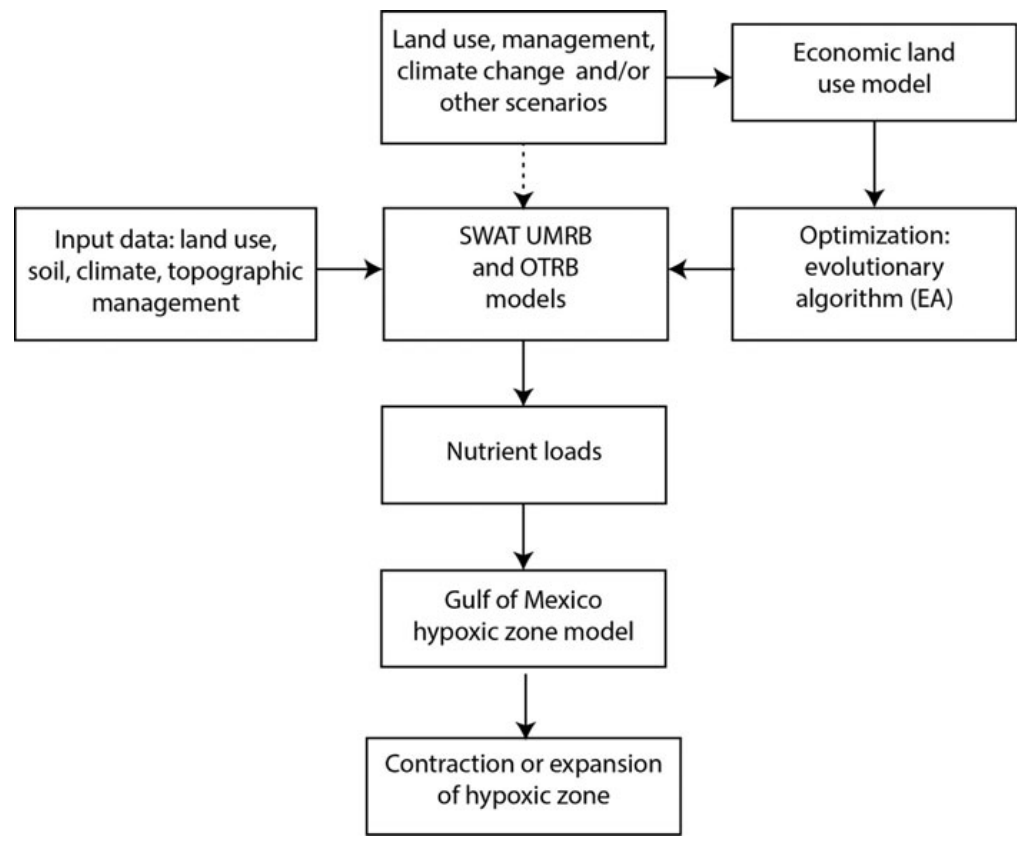

Fig. 2. Modelling schematic for LUMINATE. 


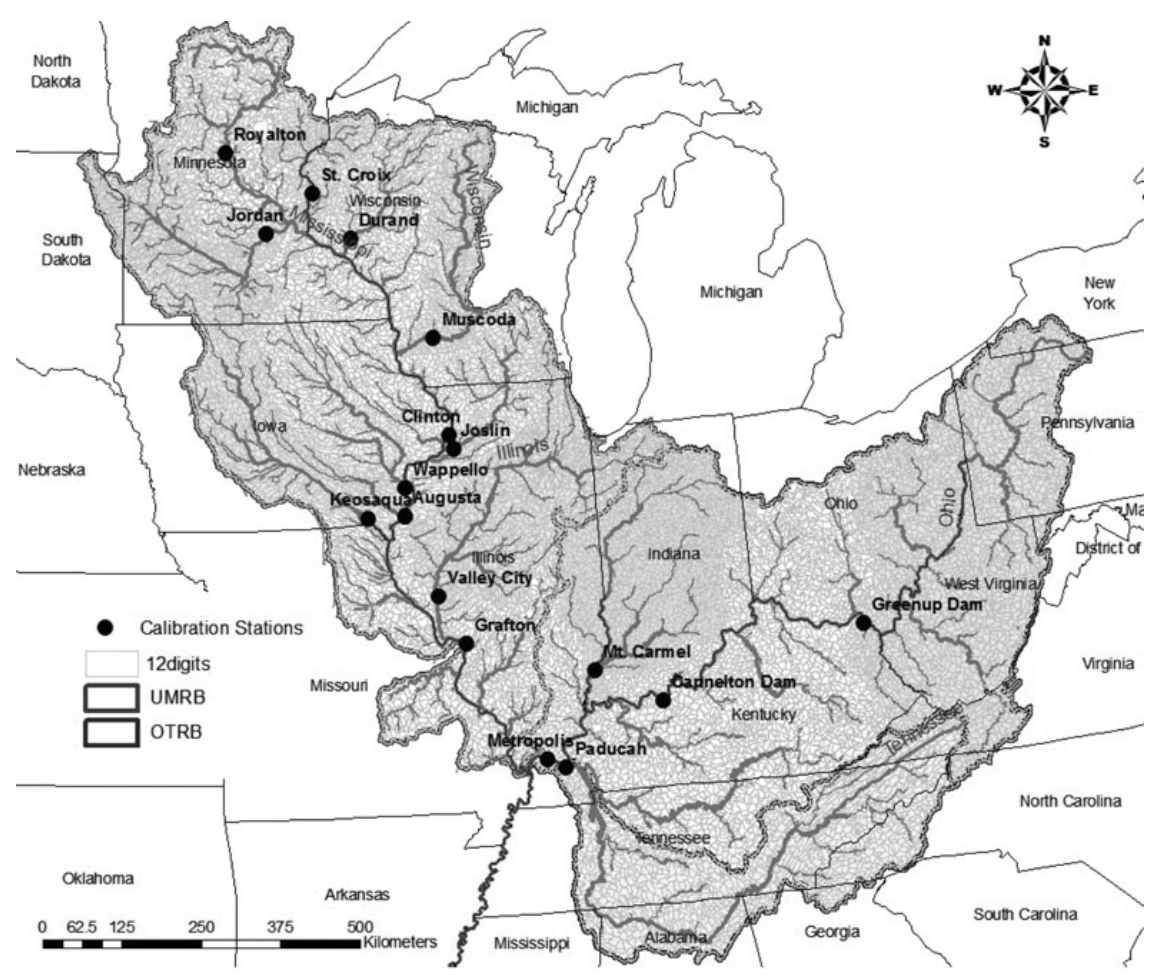

Fig. 3. Locations of the UMRB and OTRB within the United States, the main tributaries and monitoring site locations within each study region.

integration of the LUMINATE modelling system which is designed to capture the key features of this complex interaction between human decision-making, land uses across this broad landscape, and the resulting effects on water quality in the upstream watersheds as well as the Gulf of Mexico. As noted in the top-centre of the schematic, the primary purpose of the modelling system is to be able to undertake scenarios associated with changes in policy variables, weather conditions and market forces. The two key 'upstream' water quality models of this integrated system are identified in the box labelled 'SWAT UMRB and OTRB Models', which are fed and parameterised by a range of data inputs. The Soil and Water Assessment Tool (SWAT), a watershed-scale water quality model (Arnold et al., 1998; Arnold and Forher, 2005; Gassman et al., 2007), forms the core of the watershed water quality component of the modelling system proposed here and was used to construct the specific UMRB and OTRB models. As described below, the SWAT model of the region was developed to simulate a greater range of cropping systems and management practices.

Data and modelling representing economic drivers of land use are used in conjunction with scenario design to determine landscape configurations which are then fed into the SWAT modelling system. The output of this 
modelling is a spatially explicit prediction of nutrient loads and other water quality indicators throughout the basin. The final key model component of the overall modelling system is the hypoxic zone model, represented in the lower central box and which is described below.

An important feature of the modelling system built here is the ability to interface the model with an optimisation heuristic (evolutionary algorithm) for scenarios in which optimal landscape configurations to achieve a given environmental (or cost) goal are desired. While not necessary for running simple scenarios (such as the one presented in this paper), evolutionary algorithms are powerful tools for identifying and analysing trade-offs across a large range of cost and environmental objectives (see Vrugt and Robinson, 2007; Rabotyagov et al., 2010) while employing the full suite of biophysical models, allowing for consistency of assumptions and a full coupling of cost-effective policy and natural science modelling. Regardless of whether the evolutionary algorithm is employed, the modelling system is also useful in evaluating specific policy scenarios.

Previous SWAT UMRB and OTRB applications relied on delineation approaches in which the subwatershed boundaries were aligned with 8-digit watershed boundaries (e.g. Rabotyagov et al., 2010; Srinivasan, Zhang and Arnold, 2010; Secchi et al., 2011; Santhi et al., 2014). However, a greatly refined delineation scheme has been incorporated into the UMRB and OTRB SWAT models used in LUMINATE, which consist of using subwatershed boundaries that are coincident with the much smaller USGS 12-digit watersheds. This detailed subwatershed schematisation allows for improved linkages to climatic inputs, better representation of stream routing processes (and thus the non-linearities and potential endogeneities in nutrient fate and transport), and improved targeting of management practices and cropping systems on agricultural landscapes.

\section{SWAT model description and water quality modelling system}

SWAT is a conceptual, long-term continuous watershed-scale simulation model that is usually executed on a daily time step. Key components of the model include hydrology, plant growth, sediment loss and transport, nutrient transport and transformation, pesticide fate and transport, and effects of management practices. Typical applications of SWAT involve delineation of a watershed into subwatersheds, which are then further subdivided into subareas consisting of homogeneous land use, soil types and slope classes that are called hydrologic response units (HRUs). However, a ‘dominant HRU approach' can also be used in which just the dominant land use, soil, land topography are used to define the complete characteristics of a given subwatershed, resulting in the subwatershed being equivalent to a single HRU. Flow and pollutant losses are generated at the HRU level in SWAT, aggregated to the subwatershed level and then routed through the stream system to the simulated watershed outlet. SWAT has been successfully applied in extensive applications worldwide for a wide range 
of watershed scales and environmental conditions (Gassman et al., 2007; Tuppad et al., 2011; Douglas-Mankin et al., 2013; Gassman, Sadeghi and Srinivasan, 2014).

Topographic, soil, land use, climate, management and other key data are required for assembling and executing a SWAT simulation (Table 1). These data layers were assembled for the UMRB and OTRB models, and then overlaid on the subwatersheds for both regions, using the ArcGIS (version 10.1) SWAT (ArcSWAT) interface (SWAT, 2013). The dominant HRU approach described above was used for both regions such that each 12-digit subwatershed was equivalent to an HRU. Topographic characteristics such as slope and slope

Table 1. Key data layers incorporated in the UMRB and OTRB SWAT models

\begin{tabular}{|c|c|c|}
\hline Data layer & Description of data layer & Primary data sources \\
\hline Daily climate & $\begin{array}{l}\text { Daily precipitation and maximum and } \\
\text { minimum temperature; other data } \\
\text { generated in model }\end{array}$ & NCDC-NOAA (2012) \\
\hline $\begin{array}{l}\text { Soil map/layer } \\
\text { data }\end{array}$ & $\begin{array}{l}1: 250,000 \text { soil map; pertinent soil layer } \\
\text { attributes included for each soil type }\end{array}$ & $\begin{array}{l}\text { USDA-NRCS } \\
\qquad(1994 ; 2012 b)\end{array}$ \\
\hline $\begin{array}{l}\text { Major dams/ } \\
\text { reservoirs }\end{array}$ & $\begin{array}{l}\text { Key reservoirs on main channels of the } \\
\text { Ohio and Mississippi Rivers and } \\
\text { major tributaries }\end{array}$ & USACE (2012) \\
\hline Topographic & $\begin{array}{l}30 \text { m DEM data used to characterise } \\
\text { slopes and slope lengths }\end{array}$ & USGS (2006) \\
\hline Land use & $\begin{array}{l}\text { Assignment of crop rotations or other } \\
\text { landuse to each subwatershed; } \\
\text { dominant rotations were } 2 \text {-year } \\
\text { sequences of corn and soybean }\end{array}$ & USDA-NASS (2012) \\
\hline Point sources & $\begin{array}{l}\mathrm{N} \text { and } \mathrm{P} \text { discharged from thousands of } \\
\text { waste treatment plants and other point } \\
\text { sources across the two study regions }\end{array}$ & $\begin{array}{l}\text { Maupin and Ivahnenko } \\
\text { (2011) and Robertson } \\
\text { (2013) }\end{array}$ \\
\hline $\begin{array}{l}\text { Subsurface tile } \\
\text { drainage }\end{array}$ & $\begin{array}{l}\text { Installed at assumed depth of } 1.2 \mathrm{~m} \text { in } \\
\text { poorly drained and relatively flat soils } \\
(<2 \text { per cent slope })\end{array}$ & $\begin{array}{l}\text { Sugg (2007) and } \\
\text { Neitsch et al. }(2011)\end{array}$ \\
\hline Tillage practices & $\begin{array}{l}\text { No till, mulch till, reduced till and } \\
\text { conventional till practices } \\
\text { represented as a function of tillage } \\
\text { passes and residue cover and other } \\
\text { parameters }\end{array}$ & $\begin{array}{l}\text { Baker (2011) and } \\
\text { Neitsch } \text { et al. }(2011)\end{array}$ \\
\hline $\begin{array}{l}\text { Fertiliser and } \\
\text { manure }\end{array}$ & $\begin{array}{l}\text { Nitrogen and phosphorus rates applied in } \\
\text { inorganic fertiliser and manure; } \\
\text { average rates used for landscapes } \\
\text { located within each state }\end{array}$ & IPNI (2010) \\
\hline $\begin{array}{l}\text { Other } \\
\text { conservation } \\
\text { practices }\end{array}$ & $\begin{array}{l}\text { Proxy approach used to represent } \\
\text { terraces, contouring and other } \\
\text { practices as a function of slope and } \\
\text { slope length }\end{array}$ & $\begin{array}{l}\text { USDA-NRCS }(2012 \mathrm{a}) \text {, } \\
\text { Arabi et al. }(2008) \text { and } \\
\text { Neitsch et al. }(2011)\end{array}$ \\
\hline
\end{tabular}


length were incorporated for each subwatershed using a $30 \mathrm{~m}$ digital elevation model (DEM) USGS 2013). Crop rotations and other land use were incorporated by utilising 3 years (2008-2010) of the field-level USDA-NASS Cropland Data Layer datasets (USDA-NASS, 2012) with the 2001 National Land Cover Data (USGS, 2012b), similar to the approach used by Srinivasan, Zhang and Arnold (2010). Dominant soil types and soil layer characteristics were determined by using 1:250,000 State Soil Geographic (STATSGO) soil data (USDA-NRCS, 2012b). Major reservoirs are accounted for in both models based on data obtained from USACE (2012).

Management practices accounted for in the SWAT models (Table 1) included subsurface tile drains, tillage practices, fertiliser and manure application rates, and indirect accounting of other conservation practices such as terraces and contouring due to a lack of spatial estimates of such practices. The assignment of subsurface drainage tiles, which are key conduits of nitrate to surface waters, to specific subwatersheds was based on spatial distributions estimated by Sugg (2007) and soil/landscape properties. Tillage practices were imputed to specific subwatersheds by disaggregating distributions of tillage practices, which were compiled at the 8-digit watershed level by Baker (2011), to the 12-digit watershed level (while maintaining the overall 8-digit distributions to the extent possible). Nutrients applied to cropland ranged between 117$156 \mathrm{~kg} / \mathrm{ha} \mathrm{N}$ and $25-34 \mathrm{~kg} / \mathrm{ha} \mathrm{P}$, respectively, with $\mathrm{N}$ applied only to corn, using state-level annual averages reported by IPNI (2010). The SWAT autofertilisation routine was used to simulate nutrient inputs to hay and pastureland. Point sources of $\mathrm{N}$ and $\mathrm{P}$ have also been inserted to the model based on data compiled by the US Geological Survey (USGS; Maupin and Ivahnenko, 2011; Robertson, 2013).

The UMRB and OTRB SWAT models were calibrated and validated for the 1981-2010 time period based on measured river flows, sediments and $\mathrm{N}$ and $\mathrm{P}$ loads at several locations along the rivers (Figure 3). Additional details about the development of the required data layers and management inputs for the UMRB and OTRB SWAT models as well as the calibration processes are described in Panagopoulos et al. (2014a, 2014b).

\section{Hypoxia model, specification and coefficients}

A part of the integrated assessment system is an "ecological production function' representing an empirical relationship between spring nitrate-N and TP riverine loads and the areal extent of Gulf hypoxia (similar to the model described in Rabotyagov et al., 2014). Ecological theory suggests that the extent of hypoxia should be a function of nutrient inputs. Thus, the 2008 Hypoxia Action Plan recommends a dual nitrogen and phosphorus reduction strategy. To date, statistical evidence on the impact of multiple nutrients on the size of the hypoxic zone has not been unanimous. Several studies have focused on the role of N including Scavia et al. (2003), Scavia and Donnelly (2007), Liu, Evans and Scavia (2010), and Scavia, Evans and Obenour (2013). The empirical corroboration of the importance of multiple nutrients 
has been elusive. Hypoxia formation is a complex, dynamic and heterogeneous process, potentially subject to impacts of winds, ocean currents and disruptive weather events (storms and hurricanes). Further, the history of nutrient enrichment of the Gulf may matter. Turner, Rabalais and Justic (2006) speak of 'ecosystem memory', where system attributes are carried from 1 year to the next, 'as would happen if organic matter accumulating in one year was metabolized over several years'.

Previous statistical models include Turner, Rabalais and Justic (2006), who postulated that nitrogen, phosphorus and silicate, as well as lags in nutrient inputs as short as 1 month before the July hypoxia measurement and as long as 3 years prior, would be significant in explaining hypoxic area variability. They found that nitrogen loads, as well as lagged phosphorus loads, were significant. However, the authors settled on a model having May $\mathrm{N}$ and a time trend as the regressors.

Greene, Lehrter and Hagy (2009) used backward and forward model selection procedures to choose the month of nitrogen and phosphorus concentrations and river flows to be included in the hypoxia model. May nitrogen concentrations, May river flows, and February phosphorus concentrations were found to be significant. They also found that a post-1993 dummy variable was significant, and interpreted that as potential evidence of a regime shift in the system (and the inclusion of the dummy made the impact of phosphorus non-significant).

For the LUMINATE hypoxia model, we build upon these studies and Rabotyagov et al. (2014) and estimate the area of the hypoxic as a production function relationship accounting for the role of nitrate-N and TP with the possibility of multi-year lags, cumulative nutrient impacts and the time series structure of the data. Nutrient loading data comes from the official USGS estimates (as described in Aulenbach et al., 2007). The areal extent of hypoxia (in $\mathrm{km}^{2}$ ) is postulated to depend on current and past loadings of nitrate- $\mathrm{N}\left(\mathrm{N}_{t-i}\right.$, as $\log _{10}$ transform of May USGS estimates of mainstem Mississippi River loads) and current loading of TP $\left(P_{t}, \log _{10}\right.$ transform of May USGS estimates). We test for the cumulative effects of nitrogen and phosphorus by adding 5-year cumulative loadings to the model. We explore the effect of hurricanes and unusual current conditions and their interactions with nitrogen and phosphorus. Specifically, we estimate

$$
\begin{aligned}
& \text { HypoxicZone }_{t}=\beta_{\text {intercept }}+\beta_{\text {hurricane }_{\text {Hurricane }}}+\beta_{\text {current }} \text { Current }_{t}
\end{aligned}
$$

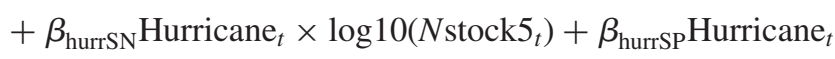

$$
\begin{aligned}
& \times \log 10\left(\text { Pstock }_{t}\right)+\beta_{\mathrm{N}} P_{t}+\sum_{i=1}^{5} \beta_{i, \mathrm{~N}} N_{t-i}+\beta_{\mathrm{Nstock} 5} N \text { Stock } 5_{t} \\
& +\beta_{\text {Pstock } 5} P \text { stock } 5_{t}+\varepsilon_{t},
\end{aligned}
$$

where $N_{t}=\log 10$ (May $\mathrm{N}$ load at time $t$ ) and $\mathrm{P}_{t}=\log 10$ (May TP load at time $t$ ) and $N$ stock $5_{t} \sum_{i=0}^{4}$ USGS-May $-N_{t-i}$ and $P$ stock $5_{t}=\sum_{i=0}^{4}$ USGS- 
May $-P_{t-i}$. We estimate the model using hypoxia size measurements from 1985 to 2010 (excluding 1989 when lack of funding precluded data collection), and use the 2011-2013 observations to assess model performance. To conserve degrees of freedom available for error estimation, we use a polynomial distributed lag model (Greene, 2003), which constrains the lagged regressors' parameters to lie on a polynomial (linear form of lag distribution). That is, the error term is assumed to follow an autoregressive process $\varepsilon_{t}=u_{t}-\theta 1 \varepsilon_{t-1}-$ $\theta_{2} \varepsilon_{t-2}$, where $u_{t} \sim N\left(0, \sigma^{2}\right)^{7}$

An additional criterion for model specification different from the specification reported in Rabotyagov et al. (2014) is the ability of the SWAT modelling framework to simulate the inputs to the statistical hypoxia model. SWAT simulations do not include silicates, and, given that the impact of silicates is estimated to be small, silicates are not included in the specification. Meteorological variables considered by Forrest, Hetland and DiMarco (2012), including 'wind power' and the Sea Surface Temperature anomalies, are only available through 2010 and given that they are outside of the nutrient management control efforts, they are implicitly left in the residual, although their effects have been reported in Rabotyagov et al. (2014). Visually, the structural part of dependence of hypoxia on single year May $\mathrm{N}$ and $\mathrm{P}$ values can be shown as a 'hypoxia production function' (Figure 4).

\section{Cover crop scenario}

Winter cover crops, including rye, oats, winter wheat or other close grown crops, are increasingly being used in the Corn Belt region to maintain and improve the quality of soil resources, and mitigate export of sediment and nutrients from cropland landscapes (Tonitto, David and Drinkwater, 2006; Kaspar and Singer, 2011; Kovar et al., 2011, 2012). In this study, the cover crop scenario consisted of planting rye within the typical 2-year rotations of corn and soybean or continuous corn, in which the rye cover crop was planted in the fall after corn or soybean harvest and then harvested shortly before planting of the following row crop in the spring.

The scenario was applied to virtually all of the cropland in both regions (slopes $<5$ per cent) that included tile-drained areas on flatter landscapes. These tile-drained landscapes are primary source areas of exported nitrate-N, which is a key water quality problem in regional stream systems (Schilling and Wolter, 2009; Jha et al., 2010; Secchi et al., 2011) and also a key contributor to the Gulf hypoxic zone. The implementation of the cover crop scenario provides an assessment of how much such widespread adoption of the practice can reduce nitrate losses from these landscapes as well as the impact of the practice on overall reduction of sediment, $\mathrm{N}$ and $\mathrm{P}$. The cover crop scenario was implemented within the same 30 -year period that the baseline testing was

7 Longer autoregressive lags in the error term were explored as well but no significant evidence for them was found. The estimated process satisfies the stationarity conditions as described in Greene (2003, p. 276). In addition, we tested and did not find significant evidence of heteroskedasticity. 


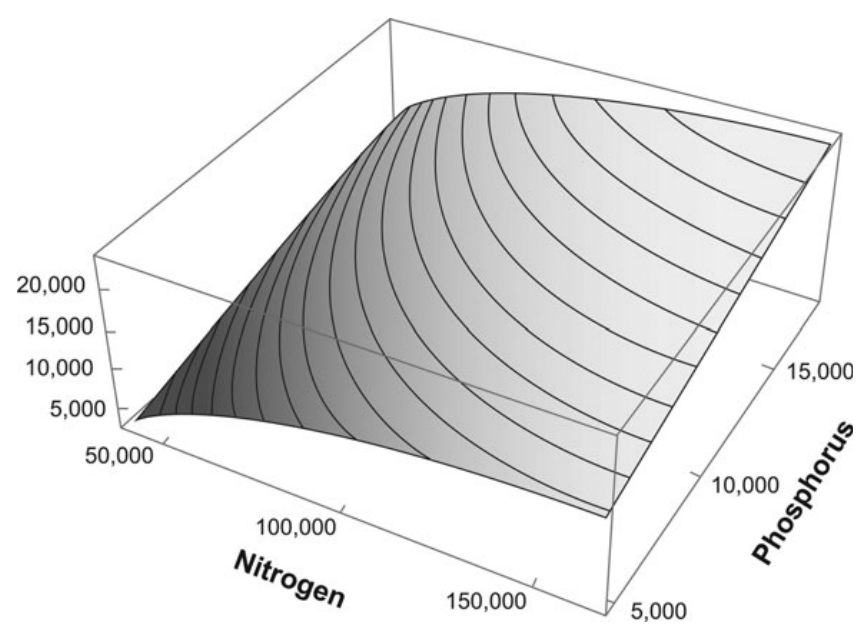

Fig. 4. Graphical representation of the empirical relationship between areal extent of hypoxia ( $z$-axis, $\mathrm{km}^{2}$ ), and $\mathrm{N}$ and $\mathrm{P}$ ( $x$ and $y$ axes, metric tons). Relationship depicted for hypothetical May 2004 loadings (lagged loadings held at historical levels).

performed for, with all other model parameters (climate, soil and other management practices) unchanged.

\section{Results and discussion}

Table 2 summarises the SWAT results of the baseline and the cover crop implementation for both the UMRB and OTRB basins. The third row of the table indicates the area of cover crop implementation in the two basins, showing the large extent of affected agricultural areas in the Corn Belt. The cover crop within the traditional rotations resulted in reduced sediment, nitrate, $\mathrm{N}$ and $\mathrm{P}$. As shown in Table 2, the reduction of all pollutants was greater in the UMRB due to the larger agricultural area where cover crops were established. Reductions were on the level of $20-25$ per cent for $\mathrm{N}$. The estimated P reduction was similar to the predicted sediment reduction due to the fact that phosphorus transport is closely tied to sediment movement.

Table 3 summarises the annual pollutant loads from both basins that enter the Mississippi River and clearly show that all of the annual pollutant loads decreased by $\sim 20$ per cent due to the widespread adoption of cover crops. Table 4 further shows annual $\mathrm{N}$ and $\mathrm{P}$ loading reductions on a unit land area basis. The $\mathrm{N}$ loadings were reduced by 5.06 and $7.97 \mathrm{~kg} / \mathrm{ha}$ in the UMRB and OTRB, respectively, while the P loadings were reduced by $0.39 \mathrm{~kg} / \mathrm{ha}$ in the UMRB and $0.72 \mathrm{~kg} / \mathrm{ha}$ in the OTRB. ${ }^{8}$ These impacts are comparable in relative magnitude with the overall $\mathrm{N}$ and $\mathrm{P}$ reductions reported in studies performed for the US Department of Agriculture Conservation Effects Assessment Project 
Table 2. Mean annual (1981-2010) SWAT results at the outlets of UMRB and OTRB under the baseline and a cover crop scenario

\begin{tabular}{|c|c|c|c|c|c|c|c|c|}
\hline \multirow{3}{*}{$\begin{array}{l}\text { Total crop area (ha) } \\
\text { Crop area }<5 \text { per cent (ha) }\end{array}$} & \multicolumn{4}{|l|}{ UMRB } & \multicolumn{4}{|l|}{ OTRB } \\
\hline & \multicolumn{4}{|l|}{$23,000,000$} & \multicolumn{4}{|l|}{$10,130,000$} \\
\hline & \multicolumn{4}{|l|}{$21,900,000$} & \multicolumn{4}{|l|}{$10,050,000$} \\
\hline Pollutant & Baseline & Cover crop & Reduction & $\begin{array}{l}\text { Reduction } \\
\text { (per cent) }\end{array}$ & Baseline & Cover crop & Reduction & $\begin{array}{l}\text { Reduction } \\
\text { (per cent) }\end{array}$ \\
\hline Flow $\left(\mathrm{m}^{3} / \mathrm{s}\right)$ & 4,095 & 4,064 & 31 & 0.75 & 7,716 & 7,681 & 35 & 0.45 \\
\hline Sediments $(t)$ & $29,008,718$ & $21,344,125$ & 766,4593 & 26.42 & $43,661,137$ & $38,265,174$ & $5,395,964$ & 12.36 \\
\hline $\mathrm{NO}_{3}-\mathrm{N}(t)$ & 405,120 & 332,558 & 72,562 & 17.91 & 313,191 & 25,6206 & 56,985 & 18.19 \\
\hline $\mathrm{TN}(t)$ & 536,361 & 425,508 & 110,853 & 20.67 & 434,581 & 35,4431 & 80,151 & 18.44 \\
\hline $\mathrm{TP}(t)$ & 40,349 & 31,877 & 8,472 & 21.00 & 48,605 & 41,403 & 7,202 & 14.82 \\
\hline
\end{tabular}


Table 3. Mean annual (1981-2010) pollutant loads entering the Mississippi River from the Corn Belt region (UMRB and OTRB) under the baseline and a cover crop scenario

\begin{tabular}{lrrrl}
\hline & Mississippi & & \\
\cline { 2 - 5 } Pollutant & \multicolumn{1}{c}{ Baseline } & Cover crop & Reduction & Per cent reduction \\
\hline Sediments $(t)$ & $72,669,856$ & $59,609,299$ & $13,060,557$ & 17.97 \\
N0 ${ }_{3}$-N $(t)$ & 718,311 & 588,764 & 129,547 & 18.03 \\
TN $(t)$ & 970,942 & 779,939 & 191,004 & 19.7 \\
TP $(t)$ & 88,954 & 73,280 & 15,674 & 17.6 \\
\hline
\end{tabular}

Table 4. Overall $\mathrm{N}$ and $\mathrm{P}$ reductions and cost estimates for reduction of each $\mathrm{kg}$ of pollutant

\begin{tabular}{|c|c|c|c|c|}
\hline & $\begin{array}{l}\text { Per cent area } \\
\text { treated }\end{array}$ & $\begin{array}{l}\text { Reductions } \\
(\mathrm{kg} / \mathrm{ha})\end{array}$ & $\begin{array}{l}\text { Cost } \\
\text { (\$/reduced kg) }\end{array}$ & $\begin{array}{l}\text { Cost } \\
\text { (\$/reduced kg) }\end{array}$ \\
\hline & & UMRB & & \\
\hline Nitrogen & \multirow[t]{4}{*}{95} & 5.06 & 12.21 & 17.14 \\
\hline Phosphorus & & 0.39 & 159.96 & 223.95 \\
\hline \multirow[t]{2}{*}{ Total costs (\$mil) } & & & $1,355.20$ & $1,897.30$ \\
\hline & & OTRB & & \\
\hline Nitrogen & 99 & 7.97 & 7.74 & 10.85 \\
\hline Phosphorus & & 0.72 & 86.35 & 120.89 \\
\hline Total costs (\$mil) & & & 621.9 & 870.7 \\
\hline Cost cover crops & & & $61.8 \$ / \mathrm{ha}(\$ 25 / \mathrm{ac})$ & $\$ 86.6 \$ / \mathrm{ha}(\$ 35 / \mathrm{ac})$ \\
\hline
\end{tabular}

(CEAP) for the UMRB and OTRB. ${ }^{9}$ However, our cover crops scenario differs from the CEAP scenarios in several aspects: (i) we consider a significantly larger treatment area, (ii) cover crops were not simulated in all of the CEAP scenarios and (iii) cover crops are just one of several conservation practices considered in the CEAP assessments. While a direct confirmation is not possible, these relative comparisons provide further support for our results. ${ }^{10}$

To provide some context for these analyses, assuming that the costs of cover crops adoption ranges from $\$ 61.8$ to $\$ 86.6 /$ ha ( $\$ 25$ to $\$ 35$ per acre), we can

9 Depending on the scenario, the $\mathrm{N}$ reductions for the UMRB range between 6.5 and 42 per cent reductions, (USDA-NRCS, 2012b), while for the OTRB they range between 12 and 50 per cent (USDA-NRCS, 2011).

10 The CEAP reports consider five conservation scenarios: the treatment of critically undertreated acres (with a high need for conservation treatment) with water erosion control practices only, water erosion practices only, but now applied to a larger share of cropland (with high or moderate need for conservation treatment, nutrient management practices simulated in addition to water erosion control practices on acres with high conservation treatment need and nutrient management practices in addition to erosion control practices on acres with high or moderate conservation treatment need. The percentage area for high and moderate need is 60 per cent in the UMRB and 70 per cent in the OTRB. Cover crops is considered a water erosion conservation practice. 
estimate that the cost of reducing a kilogram of $\mathrm{N}$ ranges between $\$ 12.02$ and $\$ 17.10$ for UMRB and between $\$ 7.74$ and $\$ 10.88$ for OTRB (Table 4). ${ }^{11,12}$

\subsection{Hypoxia model results}

The estimated statistical relationship between contemporaneous, lagged and stock levels of nutrients performs well relative to historical data and was able to predict the areal extent of the zone for 2011 and 2012 with greater precision than existing empirical models utilised by the USGS to create annual forecasts (Figure 5). ${ }^{13}$

Table 5 presents the coefficient estimates and fit statistics for the model. We find that the areal extent of hypoxia depends on $\mathrm{N}$ and $\mathrm{P}$ in fairly complex ways. As postulated in much of the existing literature, we do find that the areal extent of hypoxia (in $\mathrm{km}^{2}$ ) depends on contemporaneous spring nitrogen (May nitrate-N). However, we also find that that spring nitrogen affects the hypoxia size with up to a 5-year lag, but the multiplicative cumulative effect is moderated somewhat (as shown by the negative coefficient on the 5-year sum of May N loadings). While nitrogen affects the size of hypoxia as both a flow and a stock, phosphorus (May P) affects the size of hypoxia as a stock (Pstock5 significant and positive, $\log \mathrm{P}$ not significant). Significant impact of lagged nutrients and the significance of nutrient stocks is consistent with the proposed 'ecosystem memory' conjecture for Gulf hypoxia (Turner, Rabalais and Justic, 2006), as well as the storage of nutrients upstream in drier years (Chen and Hong, 2012). Previously, it was suggested that the system response changed post-1993 and Turner, Rabalais and Justic (2012) found a positive time trend in a model of hypoxia response to nitrogen. The stock of phosphorus is highly correlated with time $(\rho=0.71, P<0.01)$. Thus, observable variables (nutrients) which can impact hypoxia are included, instead of the time trend which proxies for accumulation of phosphorus and may include other unobservable factors.

We further find evidence for the effect of unusual current conditions and hurricanes (via their interactions with phosphorus stocks). The presence of unusual

11 The cost estimates for adopting cover crops are sparse and vary across location and type of crops. For example, Schipanski et al. (2014) estimate a cost of $\$ 63.97 /$ ha for adopting cover crops. Wainger et al. (2013) report a cost of $\$ 76.6$ per ha ( $\$ 32$ per acre). Additionally, the lowa Nutrient Strategy (IDALS, 2013) estimates a cost range $\$ 71.6$ to $\$ 80.3$ per ha ( $\$ 29$ to $\$ 32.5$ per acre).

12 A similar analysis can be made for the cost of reducing a kilogram of $P$.

13 USGS publishes annual forecasts of the hypoxic zone after May nutrient estimates are released by USGS and before the Gulf hypoxia measurements are made later in the summer. The empirical relationship in LUMINATE was used to compare its out-of-sample predictions for 2011, 2012 and 2013 hypoxia with the forecasts released by USGS, which use two alternative models, one empirical (http://www.gulfhypoxia.net/news/default.asp?XMLFilename=201306191312.xml) and another one based on the Streeter-Phelps process with calibrated parameters (http://snre.umich. edu/scavia/wp-content/uploads/2013/06/2013-Gulf-of-Mexico-Hypoxic-Forecast_UM.pdf). The LUMINATE model was most precise for 2011 and 2012 and was second-best in 2013. The model we use also exhibits the lowest root mean square error of prediction for the 2011-2013 period $(4,016$ vs. 4,225 and 7,555 for the alternative models). While an improved process-level understanding of hypoxia formation remains needed, the empirical relationship used in LUMINATE appears to be on par or better than the existing models used for hypoxia policy evaluation. 


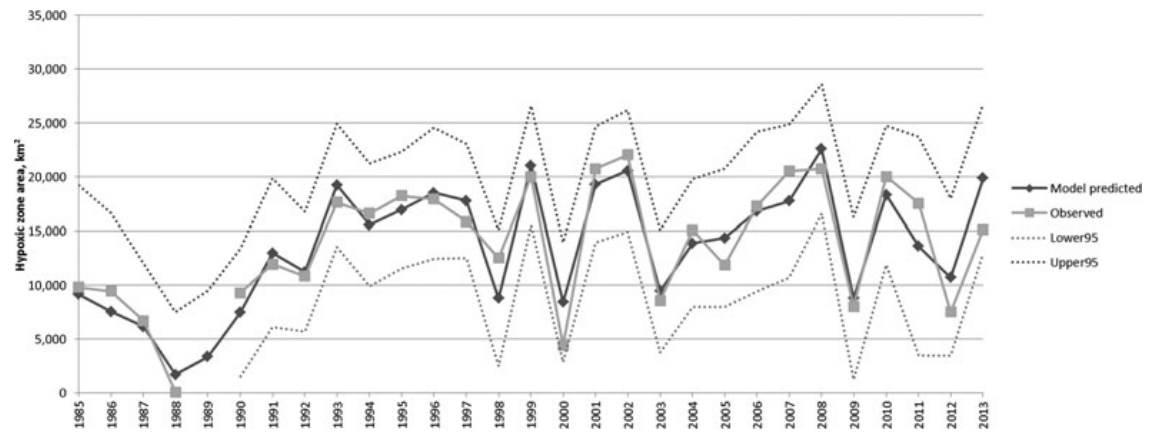

Fig. 5. Observed and model-predicted areal extent of Gulf of Mexico hypoxia, and 95 per cent confidence intervals for model prediction (2011-2013 observations were used to create out-of-sample predictions). The lower 95 per cent confidence interval bounds were estimated to be negative for 1985-1986 and 1988-1989 (lower bound for 1987 is $280.3 \mathrm{~km}^{2}$, which is too small to be shown on the graph).

Table 5. Hypoxia model parameter estimates and fit statistics

Parameter estimates

\begin{tabular}{lllrl}
\hline Variable description & \multicolumn{3}{c}{ Standard } & \\
\hline Intercept & Estimate & error & $t$-value & $P$-value \\
Hurricane & -670443 & 170396 & -3.93 & 0.0017 \\
Currents & 164110 & 183151 & 0.90 & 0.3865 \\
Log10(current year $t$ May N) & -13637 & 2776 & -4.91 & 0.0003 \\
Log10(year $t-1$ May N) & 29362 & 9630 & 3.52 & 0.0038 \\
Log10(year $t-2$ May N) & 24844 & 8381 & 3.50 & 0.0039 \\
Log10(year $t-3$ May N) & 20321 & 5936 & 3.48 & 0.0041 \\
Log10(year $t-4$ May N) & 15797 & 4767 & 3.42 & 0.0045 \\
Log10(year $t-5$ May N) & 11273 & 3681 & 3.31 & 0.0056 \\
log10P, year $t$ TP & 6803 & 4961 & 3.06 & 0.0091 \\
$N$ stock5 & -0.0827 & 0.0336 & -2.46 & 0.1935 \\
$P$ stock5 & 0.4424 & 0.0854 & 5.18 & 0.0285 \\
hurrStockN5 & 283848 & 187917 & 1.51 & 0.0002 \\
hurrStockP5 & -371761 & 192792 & -1.93 & 0.1548 \\
AR1 $\left(\theta_{1}\right)$ & 0.4043 & 0.1628 & 2.48 & 0.0759 \\
AR2 $\left(\theta_{2}\right.$ ) & 0.8117 & 0.1511 & 5.37 & 0.0274 \\
Model fit & & & & 0.0001 \\
Regression $R^{2}$ & & 0.9503 & Observations & 25 \\
Total $R^{2}$ & & 0.9085 & df error & 13 \\
SBC & & 485.372678 & AIC & 470.746168 \\
Log likelihood & & -223.37308 & & \\
Durbin-Watson & 2.5251 & & \\
\hline & & & & \\
\hline
\end{tabular}


currents has a negative impact on the size of the hypoxic zone $(P<0.01)$. Hurricanes are a major disturbance and may affect current and future hypoxia formation in complicated ways. While hurricanes, by mixing the water column, may reduce the size of hypoxia, hurricanes may also be increasing oxygen demand from the sediments, so the net impact of a hurricane is an empirical question. Across hypoxia observations from 1985 to 2013, the average size of the hypoxic zone is $12,825 \mathrm{~km}^{2}$ for non-hurricane years and $16,630 \mathrm{~km}^{2}$ for years in which hurricanes were observed (a univariate $t$-test, assuming unequal variances, yields a $P$-value of 0.052). ${ }^{14}$ In the model, the null hypothesis of no impact of hurricanes is rejected with $P<0.001$. We find that the impact of hurricanes appears to be interacting with nutrients, especially phosphorus.

\subsection{Cover crops scenario and estimated impact on Gulf hypoxia}

The empirical model of Gulf hypoxia is estimated using USGS May nitrogen and phosphorus load estimates for the amount of nutrients reaching the Gulf of Mexico, while the cover crops scenario presented in this paper simulates load reductions at the outlets of the Upper Mississippi and at the OTRBs. Therefore, a link between the scenario and its impact on nutrient loads to the Gulf needs to be created. We follow a simple procedure and use (i) USGS-reported estimates for nutrient loadings originating from the UMRB and the OTRB and (ii) estimated delivery ratio in the mainstem of the Mississippi River for nitrogen and phosphorus from White et al. (2014). ${ }^{15}$ Using this information, along with SWAT-simulated impact of cover crops on May N and P, we compute the relative reduction in the nutrient loads to the Gulf and use the adjusted nutrient values as inputs into the empirical model of the hypoxic zone. Keeping loads from other contributing basins (Missouri, Arkansas-White-Red and Lower Mississippi) constant, we assume that each nutrient's monthly load unit reduction contributes $d_{j}\left(1-r_{i j t}\right)$ units of reduction to the Gulf, where $j=\mathrm{N}, \mathrm{P}, i=$ UMRB, OTRB and $t=1981, \ldots, 2010$, and where $r_{i j t}$ represents the SWAT model-simulated reductions in monthly nutrient loads. Weighing the USGS estimates of $\mathrm{N}$ and $\mathrm{P}$ loads from the UMRB and OTRB by these factors, we adjust the USGS estimates of $\mathrm{N}$ and $\mathrm{P}$ reaching the Gulf, and employ the final estimates in creating the counterfactual cover crops scenario. We assume a fixed delivery ratio of 0.87 for $\mathrm{N}$ and 0.9 for $\mathrm{P}$, using estimates from White et al. (2014). Table 6 presents estimates of May $\mathrm{N}$ and $\mathrm{P}$ load reductions as simulated by SWAT.

Note that in comparison with mean annual $\mathrm{N}$ and $\mathrm{P}$ reductions (Table 2), simulated May mean $\mathrm{N}$ reduction is comparable with the annual values for the UMRB while quite smaller for the OTRB (Table 6). Impacts on P are simulated to be a relatively small reduction for the UMRB and a small net gain in

14 A non-parametric Mann-Whitney test (one-sided) yields a $P$-value of 0.07 .

15 USGS estimates of nutrient flux at the outlet of UMRB (http://toxics.usgs.gov/hypoxia/mississippi/ flux_ests/major_basins/MISS-THEB.html) and OTRB (http://toxics.usgs.gov/hypoxia/mississippi/ flux_ests/major_basins/OH-GRAN.html) were used. 
Table 6. Simulated percentage reductions in N and P, 1981-2010

\begin{tabular}{|c|c|c|c|c|}
\hline \multirow[b]{2}{*}{ Year } & \multicolumn{2}{|l|}{ UMRB } & \multicolumn{2}{|l|}{ OTRB } \\
\hline & $\begin{array}{l}\text { Per cent reduction } \\
\text { in May N }\end{array}$ & $\begin{array}{l}\text { Per cent reduction } \\
\text { in May P }\end{array}$ & $\begin{array}{l}\text { Per cent reduction } \\
\text { in May N }\end{array}$ & $\begin{array}{l}\text { Per cent reduction } \\
\text { in May } \mathrm{P}\end{array}$ \\
\hline 1981 & 38.8 & 14.4 & 36.1 & -3.6 \\
\hline 1982 & 0.2 & 8.3 & -15.8 & -7.1 \\
\hline 1983 & 34.6 & 13.1 & 16.9 & -3.9 \\
\hline 1984 & -34.4 & 3.7 & -13.0 & -5.1 \\
\hline 1985 & 36.9 & 9.2 & 19.9 & -0.3 \\
\hline 1986 & -1.5 & 8.0 & -5.2 & 1.8 \\
\hline 1987 & 19.7 & 8.3 & 15.7 & -3.9 \\
\hline 1988 & -0.2 & 4.2 & -4.3 & -5.7 \\
\hline 1989 & 28.3 & 11.0 & 31.8 & 5.7 \\
\hline 1990 & 7.9 & 8.7 & -2.2 & 3.1 \\
\hline 1991 & 43.3 & 14.5 & 9.2 & -6.9 \\
\hline 1992 & 0.6 & 7.2 & -4.9 & -4.1 \\
\hline 1993 & 40.0 & 21.3 & 11.8 & -2.7 \\
\hline 1994 & -2.1 & 9.0 & 5.7 & 4.3 \\
\hline 1995 & 40.5 & 10.8 & 27.2 & 1.3 \\
\hline 1996 & -10.0 & 2.4 & -12.4 & -2.1 \\
\hline 1997 & 36.6 & 7.5 & 19.3 & -1.7 \\
\hline 1998 & -11.4 & 5.7 & -6.0 & 2.3 \\
\hline 1999 & 41.4 & 9.9 & 11.6 & -0.9 \\
\hline 2000 & 12.0 & 15.4 & 2.5 & -1.9 \\
\hline 2001 & 40.7 & 10.8 & 32.1 & -4.5 \\
\hline 2002 & 8.3 & 9.4 & -2.7 & 4.2 \\
\hline 2003 & 30.8 & 14.3 & 18.3 & 0.7 \\
\hline 2004 & -18.3 & 4.3 & -19.9 & -4.4 \\
\hline 2005 & 45.2 & 14.4 & 12.6 & -1.4 \\
\hline 2006 & -4.0 & 13.2 & -12.2 & -2.7 \\
\hline 2007 & 24.8 & 5.9 & 3.8 & -5.3 \\
\hline 2008 & -7.4 & 4.4 & -10.5 & -5.0 \\
\hline 2009 & 42.2 & 11.7 & 26.4 & 1.8 \\
\hline 2010 & -8.5 & 5.2 & -1.5 & 1.9 \\
\hline Mean & 15.8 & 9.5 & 6.3 & -1.5 \\
\hline SD & 22.8 & 4.3 & 15.7 & 3.5 \\
\hline
\end{tabular}

monthly P values for OTRB (although the annual P reductions are significant in both basins). In the cover crops scenario, May nitrogen loads reaching the Gulf are reduced by 14.7 per cent, on average $(\mathrm{SD}=24$ per cent), while May phosphorus loads are reduced by 8.6 per cent, on average $(\mathrm{SD}=6$ per cent), over the period of 1981-2010.

Estimated expected hypoxia reductions are sizeable (mean annual reduction in the size of the zone is estimated to be 47 per cent), although the effectiveness of the scenario varies significantly over the simulation period, as would be 


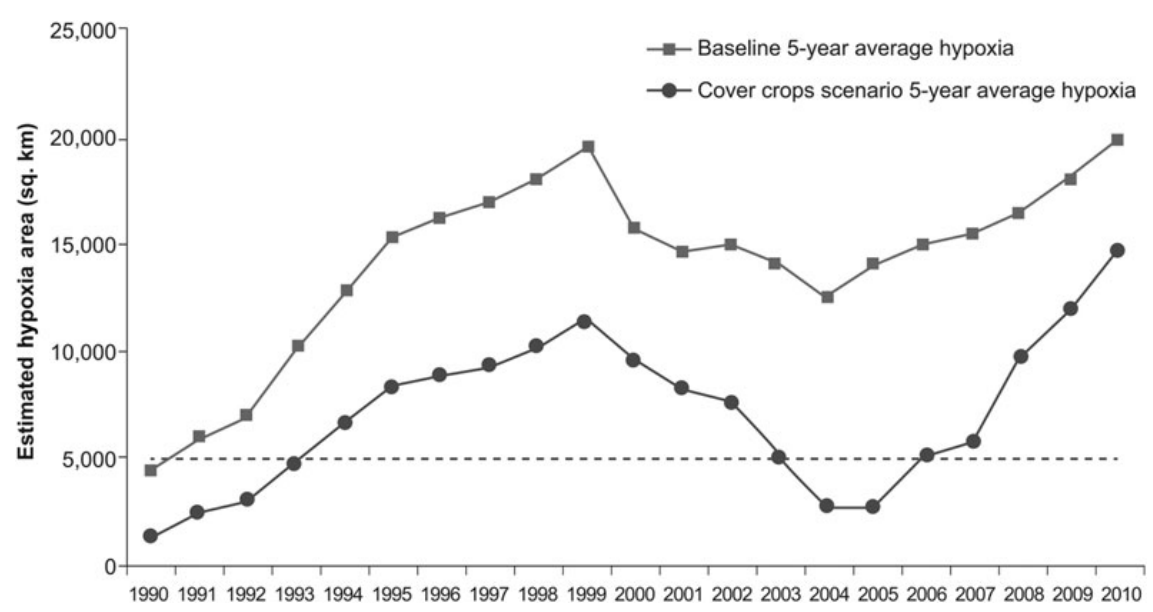

Fig. 6. The annual baseline and counterfactual hypoxia scenarios, 5-year mean hypoxia, 1990-2010 (structural component of the estimated relationship is used).

expected given variable reductions in spring nutrients simulated by SWAT. The national hypoxia Action Plan sets the target in terms of a 5-year running average of the hypoxic zone, which suggests that a smoothed relationship may be of interest to policymakers. Figure 6 presents the baseline scenario and the simulated impact of widespread application of cover crops on the 5-year average of the Gulf hypoxic zone. The Action Plan target of $5,000 \mathrm{~km}^{2}$ is depicted by a dashed line. These results suggest that the cover crops scenario is likely not sufficient to reach the goal. The mean 5-year hypoxia is estimated to be 7,175 $\left(\mathrm{SD}=3,590 \mathrm{~km}^{2}\right)$ and the hypoxia goal is reached in less than one-third of the 5-year periods between 1990 and 2010.

The results simulated by SWAT suggest that cover crops are generally effective in reducing $\mathrm{N}$ and $\mathrm{P}$, especially in terms of reducing total annual nutrient loads. Spring nutrient load per cent reductions due to cover crops are simulated to be significantly smaller than annual reductions, which is reasonable given that cover crops are most effective at mitigating nutrient loss when traditional crops are not demanding nutrients. The reduction of pollutants at the local watershed level and specifically in densely cropped areas is much higher than the reduction at the outlet of the UMRB/OTRB which drains to the Gulf. This fact highlights the important benefits of pollution mitigation in intensively managed areas where local environmental problems exist and need remediation.

The establishment of rye as a winter cover crop is effective in reducing soil erosion, as well as sediment-bound and soluble forms of nutrients, and the results here are generally in agreement with estimated impacts reported by IDALS (2013). Combining cover crops with other conservation practices would be expected to be even more effective in reducing soil and nutrient pollutant losses. The findings on the impact of cover crops on Gulf hypoxia are consistent with the existing literature. 
The 2001 Action Plan estimated that a 30 per cent reduction in the nitrogen load would likely be needed to achieve the hypoxia target. Subsequent research called for nitrogen load reductions closer to 35-45 per cent (Justić, Turner and Rabalais, 2003; Scavia et al., 2003). Rabotyagov et al. (2014), using a similar empirical relationship, found that simultaneous 30 per cent reduction in spring $\mathrm{N}$ and $\mathrm{P}$ would have been sufficient to reduce the size of the hypoxic zone to $<5,000 \mathrm{~km}^{2}$ The preliminary evidence based on our integrated modelling suggests that even a widespread adoption of cover crops, while likely having a fairly large impact in terms of hypoxia reduction, appears not sufficient in terms of reaching the national Gulf hypoxia goal.

\section{Summary and final remarks}

In this paper, we highlight the importance of developing integrated assessment models to support the design and implementation of policies to address water quality problems associated with agricultural pollution at multiple scales. We point to this emerging recognition and provide some examples of existing attempts at integrated modelling in the United States, Europe and Asia before turning our attention to large agriculture-dominated landscapes in the central US Corn Belt region. We describe a new modelling system, LUMINATE, which links land use decisions made at the field scale in the Upper Mississippi, Ohio and Tennessee Basins with local water quality effects and hypoxia in the Gulf of Mexico. We illustrate the model's capabilities with a simple scenario where cover crops are implemented over a large expanse of the watersheds. In future work, we plan to integrate the LUMINATE modelling system with evolutionary algorithms to find spatially optimised locations for the placement of cover crops and other conservation practices to achieve a wide range of environmental improvements. Optimisation using the same set of data and modelling assumptions used to develop the natural science policy basis can better serve to elucidate trade-offs, to highlight the potential gains from well-designed policies and to provide the basis for evaluating practical (if second-best) policies. Future integration with large-scale models of farmer behaviour, future climate scenarios and incorporation of other ecosystem service values (e.g. Wainger et al., 2013) and terrestrial and marine models will be pursued. The systems which could be studied using integrated models of this sort are quite diverse in terms of their natural, economic and institutional characteristics, which promises plenty of opportunity for productive research by agricultural and resource economists.

\section{Funding}

The work reported in this paper was supported by the National Science Foundation, Dynamics of Coupled Natural and Human Systems Program, award DEB-1010259 and USDA Agriculture and Food Research Initiative grants \#2011-68005-30411 and 2011-68002-30190. 


\section{References}

Alexander, R. B., Smith, R. A., Schwarz, G. E., Boyer, E. W., Nolan, J. V. and Brakebill, J. W. (2007). Differences in phosphorus and nitrogen delivery to the Gulf of Mexico from the Mississippi River Basin. Environmental Science \& Technology 42(3): 822-830.

Arabi, M., Frankenberger, J. R., Engel, B. A. and Arnold, J. G. (2008). Representation of agricultural conservation practices with SWAT. Hydrological Processes 22(16): 3042-3055.

Arnold, J. G., Srinivasan, R., Muttiah, R. S. and Williams, J. R. (1998). Large area hydrologic modeling and assessment part I: model development1. JAWRA Journal of the American Water Resources Association 34(1): 73-89.

Arnold, J. G. and Fohrer, N. (2005). SWAT2000: current capabilities and research opportunities in applied watershed modelling. Hydrological processes 19(3): 563-572.

Aulenbach, B. T., Buxton, H. T., Battaglin, W. A. and Coupe, R. H. (2007). Streamflow and nutrient fluxes of the Mississippi-Atchafalaya River basin and subbasins for the period of record through 2005. US Geological Survey.

Baker, N. T. (2011). Tillage practices in the conterminous United States, 1989-2004 datasets aggregated by watershed. Data Series 573. Reston, Virginia: US Geological Survey. Available at: http://pubs.usgs.gov/ds/ds573/.

Barbier, E. B. (2012). Progress and challenges in valuing coastal and marine ecosystem services. Review of Environmental Economics and Policy 6: 1-19.

Booth, M. S. and Campbell, C. (2007). Spring nitrate flux in the Mississippi River basin: a landscape model with conservation applications. Environmental Science \& Technology 41(15): 5410-5418.

Broussard, W. and Turner, R. E. (2009). A century of changing land-use and water-quality relationships in the continental US. Frontiers in Ecology and the Environment 7(6): 302-307.

Burkart, M. R. and James, D. E. (1999). Agricultural-nitrogen contributions to hypoxia in the Gulf of Mexico. Journal of Environmental Quality 28(3): 850-859.

Chen, N. and Hong, H. (2012). Integrated management of nutrients from the watershed to coast in the subtropical region. Current Opinion in Environmental Sustainability 4(2): $233-242$.

Chislock, M. F., Doster, E., Zitomer, R. A. and Wilson, A. E. (2013). Eutrophication: causes, consequences, and controls in aquatic ecosystems. Nature Education Knowledge 4(4): 10. Available at http://www.nature.com/scitable/knowledge/library/eutrophication-causesconsequences-and-controls-in-aquatic-102364466.

Doering, O. C., Ribaudo, M., Diaz-Hermelo, F., Heimlich, R., Hitzhusen, F., Howard, C., Kazmierczak, R. F., Jr., Lee, J., Libby, L., Milon, W., Peters, M. and Prato, A. (2001). Economic analysis as a basis for large-scale nitrogen control decisions: reducing nitrogen loads to the Gulf of Mexico. The Scientific World Journal 1: 968-975.

Donner, S. D., Coe, M. T., Lenters, J. D., Twine, T. E. and Foley, J. A. (2002). Modeling the impact of hydrological changes on nitrate transport in the Mississippi River Basin from 1955 to 1994. Global Biogeochemical Cycles 16(3): 1-19.

Douglas-Mankin, K. R., Daggupati, P., Sheshukov, A. Y. and Barnes, P. L. (2013). Paying for sediment: Field-scale conservation practice targeting, funding, and assessment using the Soil and Water Assessment Tool. Journal of Soil and Water Conservation 68(1): 41-51. 
Elofsson, K., Folmer, H. and Gren, I. M. (2003). Management of eutrophicated coastal ecosystems: a synopsis of the literature with emphasis on theory and methodology. Ecological Economics 47(1): 1-11.

Forrest, D. R., Hetland, R. D. and DiMarco, S. F. (2012). Corrigendum: Multivariable statistical regression models of the areal extent of hypoxia over the Texas-Louisiana continental shelf. Environmental Research Letters 7(1): 019501.

Gassman, P. W., Reyes, M. R., Green, C. H. and Arnold, J. G. (2007). The soil and water assessment tool: historical development, applications, and future research directions. Transactions of the ASABE 50(4): 1211-1250.

Gassman, P. W., Sadeghi, A. M. and Srinivasan, R. (2014). Applications of the SWAT model special section: overview and insights. Journal of Environmental Quality 43(1): 1-8.

Greene, R. M., Lehrter, J. C. and Hagy, J. D., III. (2009). Multiple regression models for hindcasting and forecasting midsummer hypoxia in the Gulf of Mexico. Ecological Applications 19(5): 1161-1175.

Greene, William H. (2003). Econometric Analysis. 5th ed. New Jersey: Prentice-Hall.

Greenhalgh, S. and Sauer, A. (2003). Awakening the dead zone: an investment for agriculture, water quality, and climate change. World Resources Institute. Available at http:// www.wri.org/publication/awakening-dead-zone.

Huang, L., Nichols, L. A., Craig, J. K. and Smith, M. D. (2012). Measuring welfare losses from hypoxia: the Case of North Carolina Brown Shrimp. Marine Resource Economics 27(1): 3-23.

IDALS. (2013). Iowa Nutrient Reduction Strategy: A science and technology-based framework to assess and reduce nutrients to Iowa waters and the Gulf of Mexico. Ames, IA: Prepared by: Iowa Department of Agriculture and Land Stewardship (IDALS), Des Moines, IA; Iowa Department of Natural Resources (IDNR), Des Moines, IA; and Iowa State University College of Agriculture and Life Sciences (ISUCALS) http://www.nutrientstrategy. iastate.edu/documents.

IPNI. (2010). A preliminary Nutrient use Geographic Information System (NuGIS) for the US International Plant Nutrition Institute (IPNI), Norcross, GA. Available at: http:// Www.ipni.net/nugis.

Jenkins, W. A., Murray, B. C., Kramer, R. A. and Faulkner, S. P. (2010). Valuing ecosystem services from wetlands restoration in the Mississippi Alluvial Valley. Ecological Economics 69(5): 1051-1061.

Jha, M. K., Schilling, K. E., Gassman, P. W. and Wolter, C. F. (2010). Targeting land-use change for nitrate-nitrogen load reductions in an agricultural watershed. Journal of Soil and Water Conservation 65(6): 342-352.

Johnes, P. J. and Heathwaite, A. L. (1997). Modelling the impact of land use change on water quality in agricultural catchments. Hydrological Processes 11(3): 269-286.

Justić, D., Bierman, V. J., Scavia, D. and Hetland, R. D. (2007). Forecasting Gulf's hypoxia: the next 50 years? Estuaries and Coasts 30(5): 791-801.

Justić, D., Rabalais, N. N. and Turner, R. E. (2002). Modeling the impacts of decadal changes in riverine nutrient fluxes on coastal eutrophication near the Mississippi River Delta. Ecological Modelling 152(1): 33-46.

Justić, D., Turner, R. E. and Rabalais, N. N. (2003). Climatic influences on riverine nitrate flux: implications for coastal marine eutrophication and hypoxia. Estuaries 26: 1-11. 
Karydis, M. and Kitsiou, D. (2012). Eutrophication and environmental policy in the Mediterranean Sea: a review. Environmental Monitoring and Assessment 184(8): 4931-4984.

Kaspar, T. C., Jaynes, D. B., Parkin, T. B., Moorman, T. B. and Singer, J. W. (2012). Effectiveness of oat and rye cover crops in reducing nitrate losses in drainage water. Agricultural Water Management 110: 25-33.

Kaspar, T. C. and Singer, J. W. (2011). The use of cover crops to manage soil. In J. L. Hatfield and T. J. Sauer (eds), Soil Management: Building a Stable Base for Agriculture. Madison, WI: American Society of Agronomy and Soil Science Society of America.

Khanna, M., Yang, W., Farnsworth, R. and Önal, H. (2003). Cost-effective targeting of land retirement to improve water quality with endogenous sediment deposition coefficients. American Journal of Agricultural Economics 85(3): 538-553.

Knowler, D., Barbier, E. B. and Strand, I. (2001). An open-access model of fisheries and nutrient enrichment in the Black Sea. Marine Resource Economics 16(3): 195-217.

Kovar, J. L., Moorman, T. B., Singer, J. W., Cambardella, C. A. and Tomer, M. D. (2011). Swine manure injection with low-disturbance applicator and cover crops reduce phosphorus losses. Journal of Environmental Quality 40(2): 329-336.

Liu, Y., Evans, M. A. and Scavia, D. (2010). Gulf of Mexico hypoxia: exploring increasing sensitivity to nitrogen loads. Environmental Science \& Technology 44(15): 5836-5841.

Massey, D. M., Newbold, S. C. and Gentner, B. (2006). Valuing water quality changes using a bioeconomic model of a coastal recreational fishery. Journal of Environmental Economics and Management 52: 482-500.

Maupin, M. A. and Ivahnenko, T. (2011). Nutrient loadings to streams of the continental United States from municipal and industrial effluent. Journal of the American Water Resources Association 47(5): 950-964.

NCDC-NOAA. (2012). National Climatic Data Center. Ashville, NC: National Oceanic and Atmospheric Administration. Available at: http://www.ncdc.noaa.gov/.

Neitsch, S. L., Arnold, J. G., Kiniry, J. R. and Williams, J. R. (2011). Soil and water assessment tool theoretical documentation: version 2009. U.S. Department of AgricultureAgricultural Research Service, Grassland, Soil and Water Research Laboratory, Temple, TX and Blackland Research and Extension Center, Texas AgriLife Research, Temple, TX Texas Water Resources Institute. Technical Report No. 406, Texas A\&M University System, College Station, TX. Available at http://swatmodel.tamu.edu/ documentation/ (Accessed 7 May 2014).

Panagopoulos, Y., Gassman, P. W., Arritt, R., Herzmann, D. E., Campbell, T., Jha, M. K., Kling, C. L., Srinivasan, R., White, M. and Arnold, J. G. (2014a). Surface water quality and cropping systems sustainability under a changing climate in the Upper Mississippi River Basin. Journal of Soil Water Conservation (forthcoming).

Panagopoulos, Y., Gassman, P. W., Jha, M., Kling, C. L., Campbell, T., Srinivasan, R., White, M. and Arnold, J. G. (2014b). Towards the development of an integrated modeling system for the corn belt: a refined regional modeling approach. Journal of Hydrology (to be published).

Polasky, S. and Segerson, K. (2009). Integrating ecology and economics in the study of ecosystem services: some lessons learned. Annual Review of Resource Economics 1: 409-434. 
Rabalais, N. N., Diaz, R. J., Levin, L. A., Turner, R. E., Gilbert, D. and Zhang, J. (2010). Dynamics and distribution of natural and human-caused hypoxia. Biogeosciences 7(2): 585-619.

Rabotyagov, S., Campbell, T., Jha, M., Gassman, P. W., Arnold, J., Kurkalova, L., Secchi, S., Feng, S. and Kling, C. L. (2010). Least-cost control of agricultural nutrient contributions to the Gulf of Mexico hypoxic zone. Ecological Applications 20(6): 1542-1555.

Rabotyagov, S. S., Kling, C. L., Gassman, P. W., Rabalais, N. N. and Turner, R. E. (2014). The economics of dead zones: causes, impacts, policy challenges, and a model of the Gulf of Mexico Hypoxic Zone. Review of Environmental Economics and Policy 8(1): 58-79.

Rabotyagov, S. S., Valcu, A. M. and Kling, C. L. (2013). Reversing property rights: practicebased approaches for controlling agricultural nonpoint-source water pollution when emissions aggregate nonlinearly. American Journal of Agricultural Economics. aat094. Available at: http://ajae.oxfordjournals.org/content/early/2013/12/19/ajae.aat094.short.

Randhir, T. O., Lee, J. G. and Engel, B. (2000). Multiple criteria dynamic spatial optimization to manage water quality on a watershed scale. Transactions of the ASAE 43(2): 291-300.

Ribaudo, M., Hansen, L., Hellerstein, D. and Greene, C. (2008). The use of markets to increase private investment in environmental stewardship. USDA-ERS Economic Research Report 64. Available at: http://papers.ssrn.com/sol3/papers.cfm?abstract_id=1356857.

Ribaudo, M. O., Heimlich, R., Claassen, R. and Peters, M. (2001). Least-cost management of nonpoint source pollution: source reduction versus interception strategies for controlling nitrogen loss in the Mississippi Basin. Ecological Economics 37(2): 183-197.

Robertson, D. (2013). Personal communication. US Geological Survey. Available at: http://wi.water.usgs.gov/professional-pages/robertson.html.

Santhi, C., Kannan, N., White, M., Di Luzio, M., Arnold, J. G., Wang, X. and Williams, J. R. (2014). An integrated modeling approach for estimating the water quality benefits of conservation practices at the River Basin Scale. Journal of Environmental Quality 43(1): $177-198$.

Scavia, D. and Donnelly, K. A. (2007). Reassessing hypoxia forecasts for the Gulf of Mexico. Environmental Science \& Technology 41(23): 8111-8117.

Scavia, D., Evans, M. A. and Obenour, D. R. (2013). A scenario and forecast model for Gulf of Mexico hypoxic area and volume. Environmental Science \& Technology 47(18): 10423-10428.

Scavia, D., Rabalais, N. N., Turner, R. E., Justic, D. and Wiseman, W. J., Jr (2003). Predicting the response of Gulf of Mexico hypoxia to variations in Mississippi River nitrogen load. Limnology and Oceanography 48(3): 951-956.

Schilling, K. E. and Wolter, C. F. (2009). Modeling nitrate-nitrogen load reduction strategies for the Des Moines River, Iowa using SWAT. Environmental Management 44(4): $671-682$.

Schipanski, M. E., Barbercheck, M., Douglas, M. R., Finney, D. M., Haider, K., Kaye, J. P., Kemanian, A. R., Mortensen, D. A., Ryan, M. R., Tooker, J. and White, C. (2014). A framework for evaluating ecosystem services provided by cover crops in agroecosystems. Agricultural Systems 125: 12-22.

Secchi, S., Gassman, P. W., Jha, M., Kurkalova, L., Feng, H. H., Campbell, T. and Kling, C. L. (2007). The cost of cleaner water: Assessing agricultural pollution reduction at the watershed scale. Journal of Soil and Water Conservation 62(1): 10-21. 
Secchi, S., Gassman, P. W., Jha, M., Kurkalova, L. and Kling, C. L. (2011). Potential water quality changes due to corn expansion in the Upper Mississippi River Basin. Ecological Applications 21(4): 1068-1084.

Selman, M., Greenhalgh, S., Diaz, R. and Sugg, Z. (2008). Eutrophication and hypoxia in coastal areas: a global assessment of the state of knowledge. World Resources Institute 284, March, 1-6.

Shortle, J. S. and Horan, R. D. (2013). Policy instruments for water quality protection. Annual Review of Resource Economics 5: 111-138.

Smith, V.H. and Schindler, D. W. (2009). Eutrophication science: where do we go from here? Trends in Ecology \& Evolution 24(4): 201-207.

Srinivasan, R., Zhang, X. and Arnold, J. (2010). SWAT ungauged: hydrological budget and crop yield predictions in the Upper Mississippi River Basin. Transactions of the ASABE 53(5): $1533-1546$.

Sugg, Z. (2007). Assessing US farm drainage: Can GIS lead to better estimates of subsurface drainage extent. Water Resources Institute. Washington DC. Available at: http://www. wri.org/publication/assessing-u-s-farm-drainage-can-gis-lead-better-estimates-subsurfacedrainage-exten.

SWAT. (2013). ArcSWAT: ArcGIS-ArcView extension and graphical user input interface for SWAT. Temple, TX: US Department of Agriculture, Agricultural Research Service, Grassland, Soil and Water Research Laboratory. Available at: http://swat.tamu. edu/software/arcswat/.

Tilman, D., Fargione, J., Wolff, B., D’Antonio, C., Dobson, A., Howarth, R., Schindler, D., Schlesinger, W. H., Simberloff, D. and Swackhamer, D. (2001). Forecasting agriculturally driven global environmental change. Science 292(5515): 281-284.

Tonitto, C., David, M. B. and Drinkwater, L. E. (2006). Replacing bare fallows with cover crops in fertilizer-intensive cropping systems: a meta-analysis of crop yield and $\mathrm{N}$ dynamics. Agriculture, Ecosystems \& Environment 112(1): 58-72.

Tuppad, P., Douglas-Mankin, K. R., Lee, T., Srinivasan, R. and Arnold, J. G. (2011). Soil and Water Assessment Tool (SWAT) hydrologic/water quality model: extended capability and wider adoption. Transactions of the ASABE 54(5): 1677-1684.

Turner, R. E., Rabalais, N. N. and Justic, D. (2006). Predicting summer hypoxia in the northern Gulf of Mexico: Riverine N, P, and Si loading. Marine Pollution Bulletin 52(2): 139-148.

Turner, R. E., Rabalais, N. N. and Justić, D. (2012). Predicting summer hypoxia in the northern Gulf of Mexico: Redux. Marine Pollution Bulletin 64(2): 319-324.

Turner, R. K. (2000). Integrating natural and socio-economic science in coastal management. Journal of Marine Systems 25(3): 447-460.

USACE (2012). CorpsMap: National Inventory of Dams. Washington, DC: US Army Corps of Engineers. Available at: http://geo.usace.army.mil/pgis/f?p=397:1:0.

USDA-NASS (2012). Washington, DC: US Department of Agriculture, National Agricultural Statistics Service Research and Development Division. Available at: http://www. nass.usda.gov/research/Cropland/SARS1a.htm.

USDA-NRCS (2011). Assessment of the effects of conservation practices on cultivated cropland in the Ohio-Tennessee River basin. Available at: http://www.nrcs.usda.gov/Internet/ FSE_DOCUMENTS/stelprdb1046342.pdf. 
USDA-NRCS (2012a). Assessment of the effects of conservation practices on cultivated cropland in the Missouri River basin. Available at: http://www.nrcs.usda.gov/Internet/ FSE_DOCUMENTS/stelprdb1048710.pdf.

USDA-NRCS (2012b). Assessment of the effects of conservation practices on cultivated cropland in the Upper Mississippi River basin. Available at: http://www.nrcs.usda.gov/ Internet/FSE_DOCUMENTS/stelprdb1042093.pdf.

USDA-NRCS (1994). State Soil Geographic (STATSGO) Data Base: Data use information. Miscellaneous Publication Number 1492. Lincoln, NE: US Department of Agriculture, Natural Resources Conservation Service, National Soil Survey Center. Available at: http://dbwww.essc.psu.edu/dbtop/doc/statsgo/statsgo_db.pdf.

USEPA (2001). Action Plan for Reducing, Mitigating, and Controlling Hypoxia in the Northern Gulf of Mexico. Washington, DC: Office of Wetlands, Oceans, and Watersheds Available at http://water.epa.gov/type/watersheds/named/msbasin/upload/2008_11_03_ msbasin_actionplan2001.pdf.

USEPA (2008). Gulf Hypoxia Action Plan 2008 for Reducing, Mitigating, and Controlling Hypoxia in the Northern Gulf of Mexico and Improving Water Quality in the Mississippi River Basin. Washington, DC: Office of Wetlands, Oceans, and Watersheds Available at http://water.epa.gov/type/watersheds/named/msbasin/upload/2008_8_28_msbasin_ ghap2008_update082608.pdf.

USEPA (2009). The Next Generation of Tools and Actions to Restore Water Quality in the Chesapeake Bay: A Revised Report Fulfilling Section 202a of Executive Order 13508. Washington, DC: EPA. Available at http://executiveorder.chesapeakebay.net/file. axd?file $=2009$ per cent $2 \mathrm{f} 11$ per cent $2 \mathrm{f} 202 \mathrm{a}+$ Water+Quality+Report.pdf.

USEPA (2014). Watershed Assessment, Tracking \& Environmental Results: National Summary of State Information. Washington, DC: US Environmental Protection Agency. Available at: http://ofmpub.epa.gov/waters10/attains_nation_cy.control.

USEPA SAB (2007). Hypoxia in the northern Gulf of Mexico: an update by the EPA Science Advisory Board. EPA-SAB-08-004. Washington, DC, USA: EPA Science Advisory Board, US Environmental Protection Agency. Available at: http://yosemite.epa.gov/sab/ SABPRODUCT.NSF/81e39f4c09954fcb85256ead006be86e/6f6464d3d773a6ce8525708 1003b0efe! OpenDocument \&TableRow=2.3\#2.

USGS (2012a). Federal Standards and Procedures for the National Watershed Boundary Dataset (WBD). Techniques and Methods 11-A3, Chapter 3 of Section A, Federal Standards Book 11, Collection and Delineation of Spatial Data, 3rd edn. Washington, DC: US Department of the Interior, US Geological Survey, Reston, VA and US Department of Agriculture, Natural Resources Conservation Service. Available at: http://pubs. usgs.gov/tm/tm11a3/.

USGS (2006). National Elevation Dataset. Washington, DC: US Department of the Interior, US Geological Survey, Reston, VA and US Department of Agriculture, Natural Resources Conservation Service. Available at: http://ned.usgs.gov/.

USGS (2012b). National Land Cover Database (2001). Sioux Falls, SD: Multi-Resolution Land Characteristics (MRLC) Consortium, US Geological Survey (USGS), Earth Resources Observation and Science (EROS) Center. Available at: http://www.mrlc. gov/nlcd2001.php.

USGS (2013). NOAA, Partners Predict Possible Record-Setting Deadzone for Gulf of Mexico, News Release. Available at: http://www.usgs.gov/newsroom/article_pf. asp?ID=3621. 
Vrugt, J. A. and Robinson, B. A. (2007). Improved evolutionary optimization from genetically adaptive multimethod search. Proceedings of the National Academy of Sciences 104(3): 708-711.

Wainger, L. A., Van Houtven, G., Loomis, R., Messer, J., Beach, R. and Deerhake, M. (2013). Tradeoffs among ecosystem services, performance certainty, and cost-efficiency in implementation of the Chesapeake Bay total maximum daily load. Agricultural and Resource Economics Review 42(1): 196-224.

White, M. J., Santhi, C., Kannan, N., Arnold, J. G., Harmel, D., Norfleet, L., Allen, P., DiLuzio, M., Wang, X., Atwood, E., Haney, E. and Johnson, M. V. (2014). Nutrient delivery from the Mississippi River to the Gulf of Mexico and effects of cropland conservation. Journal of Soil and Water Conservation 69(1): 26-40.

Wu, J. and Tanaka, K. (2005). Reducing nitrogen runoff from the Upper Mississippi River Basin to control hypoxia in the Gulf of Mexico: Easements or taxes? Marine Resource Economics 20(2): 121-144. 